Western University

Scholarship@Western

Department of Economics Research Reports

Economics Working Papers Archive

1978

\title{
The Demand for Money in the Italian Economy: 1867-1965
}

Franco Spinelli

Follow this and additional works at: https://ir.lib.uwo.ca/economicsresrpt

Part of the Economics Commons

Citation of this paper:

Spinelli, Franco. "The Demand for Money in the Italian Economy: 1867-1965." Department of Economics Research Reports, 7815. London, ON: Department of Economics, University of Western Ontario (1978). 


\section{RESEARCH REPORT 7815}

THE DEMAND FOR MONEY IN THE

ITALIAN ECONOMY: 1867-1965

by

Franco Spinelli

April, 1978 
THE DEMAND FOR MONEY IN THE

ITALIAN ECONOMY: 1867-1965

\author{
by \\ Franco Spinelli \\ Department of Economics \\ University of Western Ontario \\ Lond on, Canada \\ N6A $5 \mathrm{C} 2$
}

May 1978

\begin{abstract}
This paper conducts an empirical analysis of the demand for money in Italy using data for the period 1867-1965. It finds that during this time this demand was a stable function of two key variables: permanent income and the rate of interest.
\end{abstract}




\section{INTRODUCTION}

Central to a quantity theory approach to Italian macroeconomic problems is the proposition that there exists a stable demand function for money there. However, consistent with the Keynesian view of appropriate role for monetary policy, dominant in Italy since the early sixties, recent research into the liquidity preference schedule has been quite limited. Furthermore there have been no studies which use a body of data covering a period longer than thirty years. 1

The research reported here estimates a number of specifications of demand for money in Italy using a century of data drawn from ISTAT (1957), De Mattia (1967) and Giarda (1968). The model employed is of a conventional form being similar to that used by Feige (1967) and Laidler and Parkin (1970) among others. 2

The central result is that there exists a stable demand for money for Italy during this period. This function is homogeneous in prices and yields parameter estimates close to those found previously for other countries. THE MODEL

Our model of the Italian monetary sector postulates that demand for money depends upon permanent income and rates of interest. Actual real money held adjusts slowly to the difference between actual and desired real balances, and permanent income is a weighted average of past actual values of income. Such a partial adjustment-adaptive expectations model can be represented by the following equations (1), (2) and (3): 


$$
\begin{array}{ll}
M_{t}^{*}=a+b Y_{t}^{*}+c r_{t} & a, b>0 c<0 \\
\vdots & \\
M_{t}-M_{t-1}=\alpha\left(N_{t}-M_{t-1}^{*}\right)+u_{t} & 0<\alpha \leq 1 \\
Y_{t}^{*}-Y_{t-1}^{*}=\beta\left(Y_{t}-Y_{t-1}\right) & 0<\beta \leq 1
\end{array}
$$

where $M^{*}$ is the desired stock of real money balances, $M$ the actual stock, $\mathrm{Y}^{*}$ and $\mathrm{Y}$ permanent and actual real income and $\mathrm{Y}$ the proxy for the opportunity cost of holding money balances.

The estimating equation which arises from this mudel (and which we call Model 4) is:

$$
\begin{aligned}
M_{t}= & a \alpha \beta+b \alpha \beta Y_{t}+c \alpha r_{t}-c \alpha(1-\beta) r_{t-1}+(2-\alpha-\beta) M_{t-1}-(1-\alpha) \\
& (1-\beta) M_{t-2}+u_{t}-(1-\beta) u_{t-1} .
\end{aligned}
$$

This study analyses the general model in its spectific forms first, dealing with the cases where $\alpha=\beta=1$ so that the estimating equation (Model 1) is:

$$
M_{t}=a+b Y_{t}^{*}+c r_{t}+u_{t}
$$

where $\alpha$ alone equals 1 so that the estimating equation (Mode1 2) is:

$$
M_{t}=a \beta+b \beta Y_{t}+c r_{t}-(1-\beta) c r_{t-1}+(1-\beta) M_{t-1}+u_{t}-(1-\beta) u_{t-1}
$$

and where $\alpha \neq 1$ and $\beta=1$ so that the estimating equation (Model 3 ) is:

$$
M_{t}=a \beta+b \beta Y_{t}+c \alpha r_{t}+(1-\alpha) M_{t-1}+u_{t}
$$

We can apply OLS to Model 1 and a standard non-1inear program to Models 2-4. 
THE DATA

These models are estimated for the period 1867-1965. The year 1867 was chosen since it marks approximately the end of the period of independence wars and the formation of the Italian state. ${ }^{3}$ The final year is chosen because it is the last year that data are available from our sources. "The money supply figures are those for broadly-defined money; the interest rate data are the rate of discount on commercial paper for the period up to 1936 and the yield on bonds for the subsequent three decades. The price level employed is the deflator for national income. 5 Money supply and income data have been centered on mid-year. All relevant variables are measured on a per capita basis. 6

Broadly speaking the rate of change of the supply of money remains fairly low and steady up to 1914 when it starts accelerating; only in 1926 Is the situation brought back under the complete control of the authorities and a decade of monetary stability follows. Low rates of money expansion also characterize the 1950s. Real income rises at a sustained rate during the period 1897-1913 and during the post World War II years, it falls in absolute value during the two conflicts and it stagnates during the first decades and the interwar period. The interest rate rises between 1909 and 1929 then falls to an historical minimum in 1934. New peaks are reached in 1943 and 1957 and a new low in 1961. The price index $(1938=100)$ oscillates between 17 and 20 up to 1914, then in few years it rises to 126 and, between 1927 and 1936, it falls back to 84. The second world conflict is also accompanied by a tremendous rate of price inflation and in 1947 the index is as high as 4,280. Subsequently and up to 1963 we have a period of price stability. 


\section{PRELTMINARY RESULTS}

Preliminary results are presented in Tables 1-4 which break the period under consideration into a number of subintervals. The reader will note that the estimated parameters are not perfectly stable, and a test for stability may be in order. We know that from a statistical point of view it is quite important to present such a test and, as a matter of fact, we will do that; however, we believe that from an analytical point of view and, in particular, from the point of view of the conduct of the optimum monetary policy what is simply required is that the values of the estimated parameters do not shift in any erratic fashion in the long run. This explains why, in our estimates, the period 1867-1936, which contains a sufficiently larger number of degrees of freedom, has also been broken into four different sub-intervals.

Table 1 shows the results of fitting the naive model (Model 1). While this model is quite unsophisticated it nonetheless yields some interesting results. In particular the coefficient on the actual real income variable is quite robust and high in absolute value with tendency to fall toward the end of the period. The proxy for the opportunity cost of holding money has a coefficient which is significant and correctly signed over the period up to 1936, after which it becomes insignificant. The important result which indicates that Model 1 is clearly unsatisfactory is the low DW-statistics. It is for this reason that we turn to Model 2 whose results are presented in Table 2.

The results in Table 2 are quite different from those in Table 1 for both the DW-statistics and the SEEs. Although rather low in absolute value, parameter $\beta$ is strongly significant indicating the serious nature of the misspecification of Mode1 1. Another interesting (and unexpected) change 
TABLE 1 - MODEL 1

\begin{tabular}{|c|c|c|c|c|c|c|c|c|}
\hline Period & a & $\mathrm{b}$ & c & $\alpha$ & $\beta$ & $\mathrm{R}^{2}$ & DW & SEE \\
\hline $67-1936$ & $\begin{array}{c}12.3221 \\
(20.0695)\end{array}$ & $\begin{array}{c}2.3920 \\
(19.4110)\end{array}$ & $\begin{array}{c}-.4225 \\
(-2.2692)\end{array}$ & {$[1.0]$} & {$[1.0]$} & .852 & .265 & .192 \\
\hline $80-1936$ & $\begin{array}{c}10.7880 \\
(23.5750)\end{array}$ & $\begin{array}{c}2.0085 \\
(21.0808)\end{array}$ & $\begin{array}{c}-.3388 \\
(-2.6310)\end{array}$ & {$[1.0]$} & {$[1.0]$} & .893 & .367 & .131 \\
\hline $90-1936$ & $\begin{array}{c}10.6847 \\
(23.2331)\end{array}$ & $\begin{array}{c}1.9390 \\
(19.5995)\end{array}$ & $\begin{array}{c}-.4263 \\
(-3.5413)\end{array}$ & {$[1.0]$} & {$[1.0]$} & .897 & .417 & .118 \\
\hline $00-1936$ & $\begin{array}{c}10.8610 \\
(16.1870)\end{array}$ & $\begin{array}{c}1.9604 \\
(13.0500)\end{array}$ & $\begin{array}{c}-.4835 \\
(-3.3710)\end{array}$ & {$[1.0]$} & {$[1.0]$} & .834 & .357 & .129 \\
\hline $10-1936$ & $\begin{array}{c}9.8968 \\
(15.7079)\end{array}$ & $\begin{array}{c}1.6057 \\
(10.4347)\end{array}$ & $\begin{array}{c}-.6590 \\
(-5.0163)\end{array}$ & {$[1.0]$} & {$[1.0]$} & .836 & .577 & .111 \\
\hline $40-1965$ & $\begin{array}{c}7.3317 \\
(8.3934)\end{array}$ & $\begin{array}{c}1.1286 \\
(9.0713)\end{array}$ & $\begin{array}{c}-.0940 \\
(-.1937)\end{array}$ & {$[1.0]$} & {$[1.0]$} & .813 & .286 & .247 \\
\hline
\end{tabular}


TABLE 2 - MODEL 2

\begin{tabular}{|c|c|c|c|c|c|c|c|c|}
\hline Period & $a$ & $\mathrm{~b}$ & c & $\alpha$ & $\beta$ & $\mathrm{R}^{2}$ & DW & SEE \\
\hline \multirow[t]{2}{*}{$1867-1936$} & 12.5880 & 2.5643 & -.0948 & {$[1.0]$} & .1735 & .990 & 1.870 & .050 \\
\hline & $(17.1311)$ & $(13.7976)$ & $(-1.3358)$ & & $(6.5088)$ & & & \\
\hline \multirow[t]{2}{*}{$1880-1936$} & 11.4385 & 2.2556 & -.1081 & {$[1.0]$} & .2133 & .987 & 1.759 & .046 \\
\hline & $(12.7410)$ & $(13.5726)$ & $(-1.6054)$ & & $(5.4585)$ & & & \\
\hline \multirow[t]{2}{*}{$1890-1936$} & 11.1904 & 2.1841 & -.1241 & {$[1.0]$} & .2327 & .984 & 1.818 & .047 \\
\hline & $(16.2004)$ & $(12.1368)$ & $(-1.6688)$ & & $(5.0049)$ & & & \\
\hline \multirow[t]{2}{*}{$1900-1936$} & 11.0876 & 2.1399 & -.1553 & {$[1.0]$} & .2200 & .976 & 1.792 & .050 \\
\hline & $(11.2808)$ & $(8.1308)$ & $(-1.8032)$ & & $(4.2004)$ & & & \\
\hline \multirow[t]{2}{*}{$1910-1936$} & 10.7527 & 2.0427 & -.1612 & {$[1.0]$} & .2139 & .960 & 1.748 & .056 \\
\hline & $(6.8063)$ & $(4.6578)$ & $(-1.5152)$ & & $(2.8419)$ & & & \\
\hline \multirow[t]{2}{*}{ 1940-1965 } & 10.1339 & 1.6325 & .0792 & {$[1.0]$} & .3133 & .987 & 1.826 & .066 \\
\hline & $(12.4206)$ & $(12.3594)$ & $(.5721)$ & & $(7.9055)$ & & & \\
\hline
\end{tabular}


TABLE 3 - MODEL 3

$\begin{array}{rccccccrr}\text { Period } & \mathrm{a} & \mathrm{b} & \mathrm{c} & \alpha & \beta & \mathrm{R}^{2} & \mathrm{DW} & \mathrm{SEE} \\ 1867-1936 & 12.8974 & 2.5786 & -.2520 & .1791 & {[1.0]} & .990 & 1.823 & .050 \\ & (14.2074) & (13.994) & (-.9157) & (6.5458) & & & & \\ 1880-1936 & 11.7912 & 2.2859 & -.2568 & .2189 & {[1.0]} & .987 & 1.672 & .046 \\ & (15.7746) & (13.4236) & (-1.2274) & (5.4450) & & & & \\ 1890-1936 & 11.6214 & 2.2010 & -.3328 & .2483 & {[1.0]} & .984 & 1.684 & .042 \\ 1900-1936 & (15.0963) & (12.8357) & (-1.7271) & (5.1173) & & & & \\ & 11.7288 & 2.2349 & -.3356 & .2326 & {[1.0]} & .975 & 1.627 & .051 \\ 1910-1936 & (10.0414) & (8.3222) & (-1.3654) & (4.1379) & & & & \\ & 11.2432 & 2.0741 & -.3964 & .2441 & {[1.0]} & .957 & 1.541 & .058 \\ 1940-1965 & (7.4715) & (5.1298) & (-1.2798) & (2.0184) & & & & .066\end{array}$




\section{TABLE 4 - MODEL 4}

\begin{tabular}{|c|c|c|c|c|c|c|c|c|}
\hline Period & a & $\mathrm{b}$ & c & $\alpha$ & $\beta$ & $\mathrm{R}^{2}$ & DW & SEE \\
\hline \multirow[t]{2}{*}{$1867-1936$} & 12.5762 & 2.5595 & -.0912 & 1.0962 & .1595 & .989 & 1.777 & .050 \\
\hline & $(17.2592)$ & $(13.8498)$ & $(-1.4091)$ & $(9.8692)$ & $(5.6909)$ & & & \\
\hline \multirow[t]{2}{*}{$1880-1936$} & 11.4597 & 2.2615 & -.1058 & 1.0258 & .2069 & .987 & 1.732 & .046 \\
\hline & $(17.2129)$ & $(13.1555)$ & $(-1.5782)$ & $(7.4971)$ & $(7.4970)$ & & & \\
\hline \multirow[t]{2}{*}{$1890-1936$} & 11.6128 & 2.2078 & -.1243 & .9929 & .2503 & .984 & 1.801 & .047 \\
\hline & $(14.4365)$ & $(12.3028)$ & $(-1.4871)$ & $(6.5071)$ & $(3.8195)$ & & & \\
\hline \multirow[t]{2}{*}{$1900-1936$} & 11.0989 & 2.1431 & -.1514 & 1.0458 & .2089 & .976 & 1.752 & .050 \\
\hline & $(11.0262)$ & $(7.9476)$ & $(-1.7937)$ & $(6.0851)$ & $(3.2764)$ & & & \\
\hline \multirow[t]{2}{*}{ 1910-1936 } & 10.6462 & 2.0115 & -.1702 & .9501 & .2302 & .960 & 1.783 & .057 \\
\hline & $(6.5058)$ & $(4.3893)$ & $(-1.3772)$ & $(3.8985)$ & $(2.8700)$ & & & \\
\hline \multirow[t]{2}{*}{$1940-1965$} & 10.0187 & 1.6128 & .0752 & .9403 & .3292 & .987 & 1.967 & .067 \\
\hline & $(11.1499)$ & $(11.0493)$ & $(.4981)$ & $(5.4199)$ & $(4.9616)$ & & & \\
\hline
\end{tabular}


is that the rate of interest coefficient takes on the wrong sign for part of the century and is at no time significantly different from zero. This result causes us to move on to the next Model 3 whose results are given in Table 3.

If we look at the SEEs, at the DW-statistics and at the values (and levels of statistical significance) of the estimated parameters $a, b$ and $c$ we hardly notice any difference between these results and those given in Table 2. It is also striking the fact that the value of the adjustment parameter $\alpha$ is quite similar to that of the adaptive expectations parameter $\beta$ we previously obtained from the estimation of Model 2. A11 this amounts to saying that at this stage we could draw two quite different conclusions. On the basis of results given in Table 2 one could argue that the demand for real money balances is a function of permanent income and actual money balances adjust within twelve months (which of course makes a lot of sense); on the contrary Table 3 seems to suggest that actual income is the proper scale variable and that actual money balances adjust on the basis of a parameter that, on average, is less than .25. We are working on annual data and the notion that just over twenty percent of any disequilibrium in the money market is cleared up in a period of twelve months is totally counterintuitive and, as a matter of fact, both the experience of other countries ${ }^{7}$ and, as we will see in a while, the empirical evidence that already exists on the demand for money in the Italian post World War II economy strengthen our suspicions. Mode1 4 distinguishes between adjustment and expectations processes. Results for that model are given in Table 4 and, at first sight, they appear to be quite good in the sense that both $\alpha$ and $\beta$ turn out to be strongly significant, $\alpha$ is never significantly different from one and $\beta$ perfectly in line 
with the values generated by Model 2. The trouble is that, although appealing, these results are not based on some sort of sound statistical evidence. Because of the poorly determined relationship between the demand for money and the rate of interest and because of the fact that the coefficients on the interest rate variable are the only ones into which $\alpha$ and $\beta$ do not enter in a symmetrical manner Table 4 does not allow us to draw any firm conclusion and to distinguish between the two lags.

THE PROBLEM OF DISCRIMINATING BETWEEN $\alpha$ AND $\beta$

In order to be able to distinguish between the two lags we first have to bypass the problem of the non-significance of the interest rate variable. Postulating a slightly different model makes this easy to do. Goldfeld (1973) has suggested that it is nominal money balances that households adjust so that the partial adjustment equation (2) should be cast in nominal terms. 8 If we follow this argument the estimating equation turns out to be (M now indicates per capita nominal balances):

$$
\begin{aligned}
\frac{M_{t}}{P_{t}}= & a \alpha \beta+b \alpha \beta Y_{t}+c \alpha r_{t}-c \alpha(1-\beta) r_{t-1}+(1-\alpha) \frac{M_{t-1}}{P_{t}}+ \\
& (1-\beta) \frac{M_{t-1}}{P_{t-1}}-(1-\beta)(1-\alpha) \frac{M_{t-2}}{P_{t-1}}+u_{t}-(1-\beta) u_{t-1}
\end{aligned}
$$

The significance of the interest rate variable is not a necessary condition any more for us to be able to discriminate between adjustment and adaptive expectations parameters since $\alpha$ and $\beta$ no longer appear symmetrically. The estimation of this expression yield the following results: 


$\begin{array}{ccccccccc}\text { Period } & \mathrm{a} & \mathrm{b} & \mathrm{c} & \alpha & \beta & \mathrm{R}^{2} & \mathrm{DW} & \text { SEE } \\ 1867-1936 & 12.5630 & 2.5638 & -.0918 & .9151 & .1925 & .990 & 1.929 & .050 \\ & (17.2629) & (13.9789) & (-1.1738) & (9.1819) & (5.1886) & & & \\ 1940-1965 & 9.9858 & 1.6101 & .0678 & .8918 & .3535 & .989 & 2.096 & .067 \\ & (12.3156) & (12.4463) & (.4253) & (5.2728) & (4.1622) & & & \end{array}$

The estimated parameters are identical with those given in Table 4(first and last rows) indicating that the estimated value of $\alpha$ and $\beta$ does not depend upon whether Model 4 or 2 is estimated. This shows clearly that the demand for money is a function of permanent income and that money balances adjust within twelve months, i.e., that Model 2 is the correct one. These conclusions are consistent with previous research. 9

\section{THE HOMOGENEITY HYPOTHES IS}

The models so far assumed that demand for real money balances is not dependent upon prices, i.e., that economic agents do not suffer from money illusion. This section tests whether this assumption is correct by incorporating the price level as an additional argument in the demand function for nominal money balances. In particular equation (1) becomes

$$
M^{*}=a+b Y_{t}^{*}+c r_{t}+d P_{t}+u_{t}
$$

and Model 2 is replaced by Model $2^{\prime}$ :

$$
\begin{aligned}
M_{t}= & a \beta_{t}+b \beta Y_{t}+c r_{t}-(1-\beta) c r_{t-1}+d P-(1-\beta) d P_{t-1} \\
& +(1-\beta) M_{t-1}+u_{t}-(1-\beta) u_{t-1}
\end{aligned}
$$

where $P$ is the natural logarithm of the general price level and, of course, $\mathrm{M}^{*}$ and $\mathrm{M}$ desired and actual nominal money balances. The results of estimating 
this expression are given in Table 2'; over the relevant periods characterized by major inflations or deflations they lend support to the hypothesis which of course is a result that hardly needs emphasis. 10 THE ERROR STRUCTURE OF MODELS 2 AND 4

Models 2 and 4 display a first-order moving average in the random error term. This problem can easily be coped with by postulating that: ${ }^{11}$

$$
\begin{aligned}
& z_{t}=u_{t}-(1-\lambda) u_{t-1} \\
& z_{t}=\rho z_{t-1}+\epsilon_{t}
\end{aligned}
$$

where $\epsilon_{t}$ is a random term with zero mean and $\sigma^{2}$ variance and $\rho$ is the autocorrelation coefficient. Then the estimating equation (Model 5) becomes:

$$
\begin{aligned}
M_{t}= & a \alpha \beta(1-\rho)+b \alpha \beta Y_{t}-b \alpha \beta \rho Y_{t-1}+c \alpha r_{t}-c \alpha(1-\beta+\rho) r_{t-1} \\
& +c \alpha(1-\beta) r_{t-2}+(2-\beta-\alpha+\rho) M_{t-1}-[(1-\beta)(1-\alpha)+ \\
& (2-\beta-\alpha) \rho] M_{t-2}-(1-\beta)(1-\alpha) \rho M_{t-3}+\epsilon_{t}
\end{aligned}
$$

The results obtained from the estimation of this equation are given in Table 5. Over the period up to 1936 the autocorrelation coefficient is relatively high and robust. The strong contrast with Table 4 is that b falls from 2.56 to 1.54 over the period $1867-1936$ and from 2.01 to 1.45 over the period 1910-1936. In addition the estimate of $\beta$, consistent with the analysis by Griliches (1961), rises from .16 to .53 and from .23 to .52 indicating that the adjustment process is distinctly faster than our preliminary results led us to believe.

Table 5 is interesting also for another reason. For the period 1940-1965 $\rho$ is not significant (which implies that Mode1 4 is already consistent with the data) and as a matter of fact we do not notice any shift in the relative values of $b$ and $\beta$. This result is quite important 


\section{TABLE $2^{\prime}$}

\begin{tabular}{|c|c|c|c|c|c|c|c|c|c|}
\hline - Period & a & b & c & d & $\alpha$ & $\beta$ & $\mathrm{R}^{2}$ & DW & SEE \\
\hline $1867-1936$ & $\begin{array}{c}15.3254 \\
(11.4947)\end{array}$ & $\begin{array}{c}3.1198 \\
(10.3079)\end{array}$ & $\begin{array}{l}-.0563 \\
(-.8388)\end{array}$ & $\begin{array}{r}.8256 \\
(13.7504\end{array}$ & {$[1.0]$} & $\begin{array}{r}.1303 \\
(4.3916\end{array}$ & .990 & 1.615 & .047 \\
\hline $1880-1936$ & $\begin{array}{l}13.3297 \\
(8.6881)\end{array}$ & $\begin{array}{c}2.6663 \\
(7.5622)\end{array}$ & $\begin{array}{r}-.0706 \\
(-1.0268\end{array}$ & $\begin{array}{c}.9008 \\
(14.1035)\end{array}$ & {$[1.0]$} & $\begin{array}{c}.1613 \\
(3.3519)\end{array}$ & .998 & 1.656 & .045 \\
\hline $1890-1936$ & $\begin{array}{l}12.3669 \\
(8.5460)\end{array}$ & $\begin{array}{c}2.4451 \\
(7.2180)\end{array}$ & $\begin{array}{r}-.0904 \\
(-1.1486\end{array}$ & $\begin{array}{r}.9382 \\
(15.4122\end{array}$ & {$[1.0]$} & $\begin{array}{c}.1929 \\
(3.3974)\end{array}$ & .998 & 1.755 & .046 \\
\hline $1900-1936$ & $\begin{array}{l}12.0221 \\
(7.3842)\end{array}$ & $\begin{array}{c}2.3412 \\
(5.9549)\end{array}$ & $\begin{array}{r}-.1227 \\
(-1.3158\end{array}$ & $\begin{array}{c}.9448 \\
(13.5891)\end{array}$ & {$[1.0]$} & $\begin{array}{c}.1834 \\
(2.8236)\end{array}$ & .998 & 1.749 & .050 \\
\hline $1910-1936$ & $\begin{array}{l}11.5135 \\
(5.9012)\end{array}$ & $\begin{array}{c}2.1709 \\
(4.2933)\end{array}$ & $\begin{array}{c}-1.2921 \\
(-1.1828)\end{array}$ & $\begin{array}{c}.9259 \\
(10.2803)\end{array}$ & {$[1.0]$} & $\begin{array}{c}.1271 \\
(2.1884)\end{array}$ & .996 & 1.672 & .052 \\
\hline $1940-1965$ & $\begin{array}{c}10.7352 \\
(15.6874)\end{array}$ & $\begin{array}{c}1.6440 \\
(16.0088)\end{array}$ & $\begin{array}{l}.0088 \\
(.733)\end{array}$ & $\begin{array}{c}.9037 \\
(29.8606)\end{array}$ & {$[1.0]$} & $\begin{array}{c}.3310 \\
(8.5984)\end{array}$ & .999 & 1.960 & .056 \\
\hline
\end{tabular}


TABLE 5 - MODEL 5

\begin{tabular}{|c|c|c|c|c|c|c|c|c|c|}
\hline Period & a & $\mathbf{b}$ & c & $\alpha$ & $\beta$ & $\rho$ & $\mathrm{R}^{2}$ & DW & SEE \\
\hline \multirow[t]{2}{*}{$1867-1936$} & 7.8046 & 1.5436 & -.1045 & 1.0954 & .5263 & .7199 & .991 & 1.723 & .44 \\
\hline & $(5.6819)$ & $(5.3483)$ & $(-1.8472)$ & $(19.0950)$ & $(7.3094)$ & $(6.6463)$ & & & \\
\hline \multirow[t]{2}{*}{$1880-1936$} & 7.9612 & 1.5403 & -.0873 & 1.0806 & .5180 & .6982 & .995 & 1.673 & .042 \\
\hline & $(4.8334)$ & $(4.7869)$ & $(-1.5391)$ & $(16.9439)$ & $(6.4296)$ & $(4.7869)$ & & & \\
\hline \multirow[t]{2}{*}{$1890-1936$} & 7.8068 & 1.5152 & -.0948 & 1.1123 & .4996 & .6363 & .992 & 1.682 & .044 \\
\hline & $(4.6497)$ & $(4.6911)$ & $(-1.4246)$ & $(14.0826)$ & $(5.1821)$ & $(3.9013)$ & & & \\
\hline \multirow[t]{2}{*}{$1900-1936$} & 7.7312 & 1.4751 & -.1400 & 1.1029 & .5337 & .6952 & .988 & 1.617 & .048 \\
\hline & $(3.7361)$ & $(3.5247)$ & $(-1.7612)$ & $(12.9196)$ & $(4.2702)$ & $(3.8682)$ & & & \\
\hline \multirow[t]{2}{*}{$1910-1936$} & 7.8775 & 1.4506 & -.1446 & 1.0872 & .5172 & .6786 & .963 & 1.611 & .056 \\
\hline & $(2.8721)$ & $(2.8293)$ & $(-1.3864)$ & $(10.1680)$ & $(3.0392)$ & $(2.0392)$ & & & \\
\hline \multirow[t]{2}{*}{ 1940-1965 } & 9.9898 & 1.6496 & .0699 & .9717 & .3211 & .0769 & .987 & 1.983 & .069 \\
\hline & $(10.1350)$ & $(9.7849)$ & $(.4776)$ & $(3.7255)$ & $(6.3148)$ & $(.1699)$ & & & \\
\hline
\end{tabular}


because it does show that over the whole century the elasticity of the demand for money with respect to permanent income has been fairly constant. The two adjustment parameters $\alpha$ and $\beta$ also turn out to be fairly stable. However since a proper test for stability is in order the period up to $1936^{12}$ has been broken into two distinct subperiods: 1867-1913, 1914-1936. Notice that the first subperiod is characterized by an extraordinary price stability and, in particular from 1897 on, by high rates of growth in contrast with the latter subperiod. ${ }^{13}$ Results are as follows:

Period

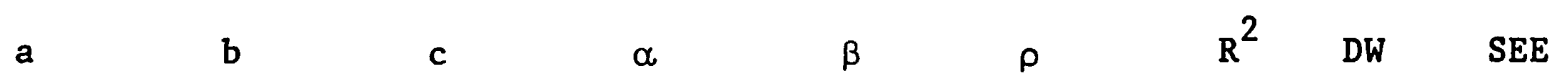

$\begin{array}{llllllllll}8.5809 & 1.7719 & -.0548 & 1.0857 & .5079 & .7201 & .989 & 1.860 & .038\end{array}$

$\begin{array}{ccccccccc}8.0861 & 1.4706 & -.1481 & 1.0746 & .5188 & .6705 & .958 & 1.589 & .061 \\ (2.7005) & (2.5906) & (-1.2791) & (9.1716) & (2.8049) & (2.5427) & & & \end{array}$

and an F-test ${ }^{14}$ reveals that they lend support to the null hypothesis. On the whole we would say that on the basis of both a priori considerations on the values of the parameters and standard statistical criteria the results we have presented in this section are interesting and make a lot of sense. The fact that they are similar to those obtained by other authors in studies on the demand for money in the U.S.A. economy is also worth stressing. ${ }^{15}$ THE EXCLUSION OF THE PERIODS OF WAR AND THE ROLE OF THE RATE OF INTEREST

This section investigates whether the picture above changes in any significant way when the two periods of war 1914-1919 and 1940-1945 are dropped. Results are given in Table 6 which tabulates our previous results as well. The estimated parameters $a, b, \alpha, \beta$ (up to 1936) and $\rho$ do not seem to be affected by the exclusion of these observations. Two features of these results are worth noting. First, over the latter period $\beta$ rises to .41 , i.e., it becomes 
TABLE 6

THE EXCLUSION OF THE PERIODS OF WAR

$\begin{array}{cccccccccc}\text { Period } & \mathrm{a} & \mathrm{b} & \mathrm{c} & \alpha & \beta & \rho & \mathrm{R}^{2} & \mathrm{DW} & \text { SEE } \\ 1867-1936 & 7.8046 & 1.5436 & -.1045 & 1.0954 & .5263 & .7199 & .991 & 1.723 & .044 \\ & (5.6819) & (5.3483) & (-1.8472) & (19.0950) & (7.3094) & (6.6463) & & & \\ \begin{array}{c}1867-1913 \\ \text { and }\end{array} & 8.5775 & 1.6912 & -.1213 & 1.0687 & .5132 & .7331 & .992 & 1.976 & .043 \\ 1919-1936 & (5.0930) & (4.8150) & (-2.1499) & (20.1096) & (7.5393) & (7.2428) & & & \\ 1940-1965 & 10.0187 & 1.6128 & .0752 & .9403 & .3292 & - & .987 & 1.967 & .067 \\ & (11.1499) & (11.0493) & (.4981) & (5.4199) & (4.9616) & & & & \\ 1946-1965 & 10.5486 & 1.5869 & -.3699 & 1.1085 & .4097 & - & .993 & 2.139 & .044 \\ & (25.5090) & (20.9638) & (-2.2833) & (7.1840) & (6.6042) & & & & \end{array}$


close to the .51 value we obtained for the previous seven decades. In addition there is a large shift in the absolute value, sign and t-statistics of the coefficient on the rate of interest which demonstrates that money holdings are responsive to interest rates.

This last result needs emphasis for two distinct reasons. On one side it is clear that it gets rid of any residual doubt or to whether we are dealing with an adaptive expectations lag or not; on the other it completely undermines the Keynesian conventional wisdom the Italian monetary policy has been based upon in all these recent years and which has been summarized as follows, "... it would appear that the interest elasticity of the demand for moncy is high and unstable, even if related to a wide definition of money which includes time deposits and short-term securities." 16

It is also appropriate here to make a couple of fairly general comments on the role of the rate of interest in a demand for money function. If we look at our results we realize that a question arises as to why, over the period up to 1936, this variable generates poor results. The reason is easy to find. As we have already said, for all these years we have no long-term rates of interest which, in the Italian institutional framework, represent a better proxy for the opportunity cost of holding money. ${ }^{17}$ We know that the more complicated the model is, the more sophisticated that proxy must be and indeed it is not a case that as we move from Mode1 1 to Model 2 our short-term rate becomes insignificant. ${ }^{18}$ Moreover, as it has been shown, Italian economic agents act on the basis of permanent income which means that the actual independent income variable is smooth and tends to capture part of the effects that should be attributed to the interest rate variable. Finally, as Laidler (1977) has pointed out, a demand for money that is a function of permanent income only is quite compatible with a systematic positive relationship between velocity and the level of interest rates 
"...to the extent that variations in the ratio of current to permanent income may be regarded as a proxy for interest rate variations." 19 A1l this in order to show that even if there only existed the kind of empirical evidence we have obtained for the period up to 1936 the hypothesis of a vertical LM-curve should have to be rejected. Of course we know more than that; on the basis of the results given in Table 6 we can say that, if properly measured, the opportunity cost of holding money does turn out to be significant in spite of the contemporaneous presence of a permanent income variable among the regressors.

A final point. We have also investigated whether there exists a liquidity trap at an interest rate different from zero. Pifer (1969) has suggested that the appropriate procedure for this is to experiment with different interest rate floors until we eventually find the 'true' minimum rate. In spite of the fact that the interest rate floors employed cover a wide range we have been complctely unable to find any result that could point toward the existence of a liquidity trap. Furthermore, a close examination of the residuals from the computed equations revealed that nowhere, during the thirties, does our model generate large underestimates of the quantity demanded which of course strengthens our conclusion that the liquidity trap hypothesis does not stand up to the facts.

THE ROLE OF THE RATE OF INFLATION

Research was done to determine whether the rate of inflation plays a role independent of its influence upon the rate of interest. In the Keynes of the Monetary Reform as well as in the Chicago tradition and particularly in the 'restated' quantity theory money is just an alternative for physical goods and the expected rate of inflation plays a prominent role in the demand function. ${ }^{20}$ To test this, the logarithm of the rate of inflation has been included among the regressors. ${ }^{21}$ Results are presented in Table 7 where $e$ is the coefficient of this regressor. 


\section{TABLE 7}

THE ROLE OF THE RATE OF INFLATION

\begin{tabular}{|c|c|c|c|c|c|c|c|c|c|c|}
\hline Period & a & b & c & e & $\alpha$ & $\beta$ & $\rho$ & $\mathrm{R}^{2}$ & DW & SEE \\
\hline $1867-1936$ & $\begin{array}{c}8.0228 \\
(4.9174)\end{array}$ & $\begin{array}{c}1.5609 \\
(4.6373)\end{array}$ & $\begin{array}{c}-.1029 \\
(-1.8609)\end{array}$ & $\begin{array}{c}-.0152 \\
(-1.7611)\end{array}$ & $\begin{array}{c}1.0744 \\
(21.3989)\end{array}$ & $\begin{array}{c}.4646 \\
(5.3319)\end{array}$ & $\begin{array}{c}.7126 \\
(6.1797)\end{array}$ & .993 & 1.784 & .043 \\
\hline $1867-1913$ & $\begin{array}{c}8.9069 \\
(3.7889)\end{array}$ & $\begin{array}{c}1.8347 \\
(3.4794)\end{array}$ & $\begin{array}{c}-.0597 \\
(-.8082)\end{array}$ & $\begin{array}{l}-.0089 \\
(-.9902)\end{array}$ & $\begin{array}{c}1.0713 \\
(17.0020)\end{array}$ & $\begin{array}{c}.4613 \\
(4.2886)\end{array}$ & $\begin{array}{c}.7097 \\
(5.0039)\end{array}$ & .988 & 1.890 & .038 \\
\hline $\begin{array}{l}1867-1913 \\
1919-1936\end{array}$ & $\begin{array}{c}9.0765 \\
(4.3369)\end{array}$ & $\begin{array}{c}1.7596 \\
(4.1280)\end{array}$ & $\begin{array}{c}-.1189 \\
(-2.1893)\end{array}$ & $\begin{array}{r}-.01689 \\
(-2.0216)\end{array}$ & $\begin{array}{c}1.0502 \\
(23.3014)\end{array}$ & $\begin{array}{c}.4331 \\
(5.9608)\end{array}$ & $\begin{array}{c}.7114 \\
(6.5885)\end{array}$ & .989 & 2.090 & .042 \\
\hline $\begin{array}{l}1940-1965 \\
=\end{array}$ & $\begin{array}{c}7.5558 \\
(5.5526)\end{array}$ & $\begin{array}{c}1.0947 \\
(4.2767)\end{array}$ & $\begin{array}{c}-.2864 \\
(-.9074)\end{array}$ & $\begin{array}{c}.2501 \\
(1.4603)\end{array}$ & {$[1.0]$} & $\begin{array}{c}.5498 \\
(5.4458)\end{array}$ & - & .953 & 2.00 & .138 \\
\hline $1946-1965$ & $\begin{array}{c}10.1758 \\
(21.8880)\end{array}$ & $\begin{array}{r}1.5295 \\
7.8462)\end{array}$ & $\begin{array}{c}-.3027 \\
(-1.9698)\end{array}$ & $\begin{array}{c}-.6312 \\
(-3.1208)\end{array}$ & $\begin{array}{c}.6489 \\
(5.6985)\end{array}$ & $\begin{array}{c}.3818 \\
(7.0457)\end{array}$ & - & .999 & 3.123 & .025 \\
\hline
\end{tabular}


Let us consider the period 1867-1936 first. Al1 the estimated parametcr seem to be unaffected by the inclusion of this extra regressor whose coefficient is correctly signed, significant of the ninety percent probability level but quite low in absolute value; moreover the explanatory power of the model docs not incrcase at all. This result was not totally unexpected.

Recent papers by Logue and Willet (1976) and by Klein (1975, 1976) examine the relationship between the level and variability of inflation on our side and its optimum expected rate on the other and come to the conclusion that, for instance, the period up to World War $I$ is a period of mean reversion in the rate of inflation in the sense that expectations must be negatively correlated with the actual rate of inflation. In particular Klein (1976) writes: "...during the gold standard period several price changes were highly variable but the absolute annual rate of price change was extremely steady and the average rate of price change was near zero. If, for example, an eight percent inflation rate occurred in a particular year, an inflation rate of approximately minus eight percent would likely occur a short time later." In Italy the period 1867-1913 is characterized by a rate of inflation which practically oscillates between minus and plus six percent 22 and which reveals a situation quite similar to the one Klein is referring to. On the basis of the results by this author, a priori, we expected to find a positive coefficient on the actual rate of inflation, at least over the period up to 1913. Instead, from Table 7 we notice that, although lower in absolute value and insignificant, $e$ is still negatively signed.

There is a further aspect that is worth investigating. It is a fact that throughout the whole of Europe, over the period 1914-1918, economic agents are convinced that at the end of the war prices will fall to the pre-war level (Einzig (1935)). In particular, in Italy there is a widespread belief that Germany is accumulating hugh quantities of commodities in gigantic storehouses in order to flood the Italian markets at the end of the war in an attempt to 
drive down prices and cause the collapse of the economic system. People are too convinced and Einaudi, the Italian leading economist, has to intervene. For instance in the Corriere della Sera (1-2 May 1915) he writes, "...how can Germany, with few workers and extraordinary military and agricultural requirements affort to produce goods...just because she wants to store them?" These words turn out to be useless; economic agents keep thinking that the higher inflation will soon turn into a higher deflation and the actual behavior of the price level during the period November 1918-March $1919^{23}$ proves this. Because of all this it is reasonable to consider the actual rate of inflation to be a very poor proxy for the expected cost of holding money balances during the war period. However even when these observations are excluded e turns out to be as slow as before, indeed too low for us to be able to draw any firm conclusion in favour of the inclusion of the rate of inflation among the regressors. 24

The picture does not become clearer as we move on to the last decades and, if anything, results are even more difficult to interpret. Here first of all we discover that over the period 1940-1965 convergence by Gauss cannot be achieved and only by constraining $\alpha$ to be equal to 1 can we overcome this technical problem. c turns out to be insignificant and with the wrong positive sign. Then, as we drop the war period in order to find out whether, thanks to the presence of a robust coefficient on the rate of interest we can get more accurate results, not only does e turn out to be correctly signed; it is also quite strong and reasonable in absolute value. However a careful scrutiny of the whole vector of estimated parameter reveals that a great care must be taken in order to avoid drawing strong and, may be even wrong conclusions. The fact that $\alpha$ falls by more than thirty percent with respect to all our previous estimates together with the consideration that, over these two decades, there is an upward trend in the rate of inflation suggests that quite probably $e$ is capturing part of the effects that should be attributed 
to $\alpha$. All in a11, we would say that the empirical evidence we have presented in this section is fairly inconclusive and that further work that takes into consideration the 'expected' rate of inflation is badly needed before any firm conclusion can be reached.

\section{CONCLUSION}

During all the years we have taken into consideration in the present study Italy experiences with monarchy and republicanism, with democracy and fascism, with right-wing and left-wing governments. Two world wars are fought and even the national border changes several times. There are periods of stagnation and periods of rapid growth, two major inflation episodes, long periods of price stability and even a decade of falling prices. Up to 1883 there are six central banks and only in 1926 does the Bank of Italy become the only bank of issue. We have periods of fixed exchange rates and peri ods of flexible exchange rates as well. The nineteenth century marks the high tide of liberalism; during the 1920s and 1930s the government intervenes heavily in the economy.

Despite all these sweeping institutional, economic and political changes, over the last century the demand for money in Italy has been a stable function of few key variables, permanent income and the rate of interest. Money balances have been found to adjust within twelve months and the adaptive expectations parameter to be equal to .4-.5 The homogeneity hypothesis is supported by our results.

From a policy point of view the message is clear. In the long run two of the three major arguments of the demand for real balances function--the natural level of income and the real rate of interest--are exogenous to the money market. The role of the price level (and of foreign assets in determining the supply of nominal money) depends upon the exchange rate regime that is adopted. In the long run, under a fixed exchange rate regime the price level 
is determined abroad ${ }^{25}$ and domestic monetary policy influences only the balance of payments. Under a flexible exchange rate regime the exchange rate clears the foreign exchange market and the quantity of money and the price level are under the control of the Bank of Italy, i.e., monetary policy becomes a powerful policy instrument. 
APPENDIX - DATA

MONEY

SUPPLY

(MILIIONS)
INCOME
(THOUSANDS)

6466

5932

6108

6337

6963

7372

8334

8087

7988

8590

9633

11016

10491

9183

9270

10397

9842

9653

10368

9303

10043

9441

9305

9970

10379

9576

9483

9654

10552

11106

9928

10075

9738

10147

10150

9890

11171

11187

11918

12269

11697

12804

12615

13267

14109

15782

14990

16287

16209

17973

18706

19459

18719

20814

28359

37392

46154

57851

88061

88893
PRICE

POPULATION INDEX

$(1938=100)$

RATE OF INTEREST

5.06

26214

26386

26561

26736

26911

27088

27267

27446

27627

27808

27991

28176

28361

28548

28735

28924

29115

29306

29499

29694

29829

30086

30284

30485

30686

30889

31094

31299

31506

31715

31924

32135

32348

32562

32777

32994

33212

33432

33653

33870

34100

34316

34580

34849

35068

35351

35724

36111

36523

36878

37088

37256

37446

37680

37813

37773

37581

37470

37593

37782
16

15

15

15
16

16
16

18

17

16

17

19

21

20

17

17

19

18

18

17

18

17

17

18

18

17

17

18

18

18

17

17

16

17

17

17

18

17

18

17

17

17

17

17

18

17

18

19

20

20

21

21

21

23

30

42

52

65

92

93
5.70

7.87

5.41

6.08

5.29

5.00

5.00

5.08

5.00

5.02

5.00

5.00

5.00

5.00

5.00

4.75

4.50

4.50

4.41

5.08

5.08

4.45

5.08

4.75

5.50

5.50

5.25

6.00

5.83

5.20

5.25

5.70

5.00

4.64

4.62

4.43

4.37

4.56

4.75

4.81

4.56

4.39

4.41

4.52

4.62

4.60

4.35

4.57

4.95

5.47

5.56

5.29

5.39

5.02

4.87

5.04

5.00

5.68

6.00 
APPENDIX - DATA (CONT'D)

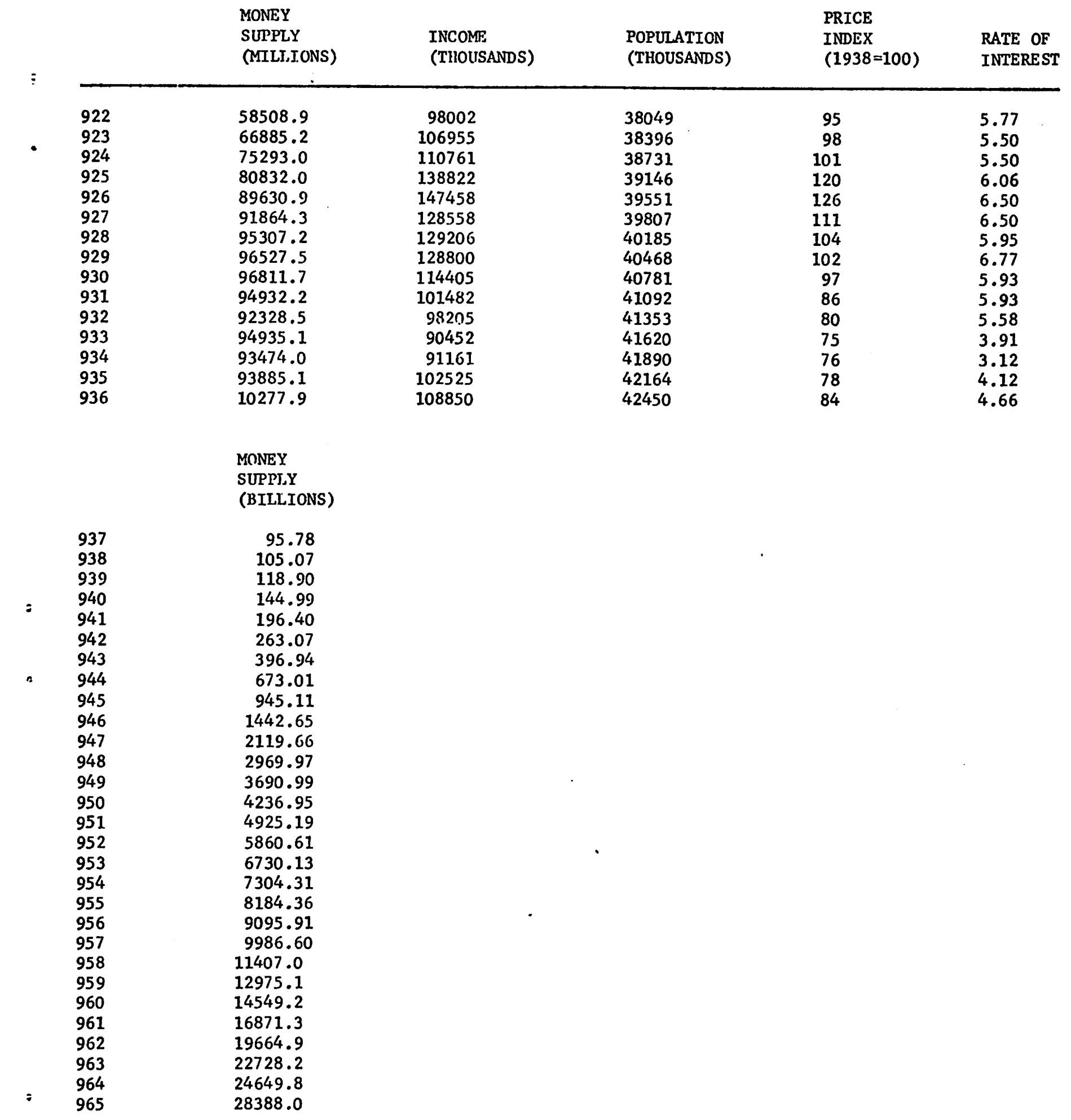


FOOTNOTES

${ }^{*}$ I benefitted from comments on a first draft of this paper presented at the Money Workshop in the University of Western Ontario. I am specially grateful to Russel Boyer, Thomas Courchene, Peter Howitt, Geoffrey Kingston, David Laidler, Michael Parkin and Aman Ullah for criticism and suggestions and to Luciano Venturini for research assistance. Errors and shortcomings are my own responstbility.

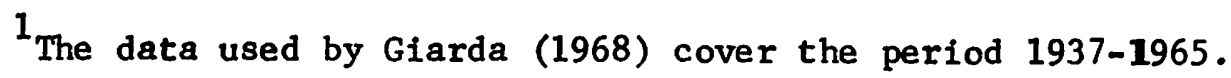

${ }^{2}$ See also Frowen and Arestis (1976) and Gray, Ward and Zis (1976).

${ }^{3}$ of course results are not affected by this choice. We experimented with 1870 and they turned out to be the same.

${ }^{4}$ Three major and distinct data sources have been utilized: ISTAT (1957), De Mattia (1967) whose data on the supply of money and interest rates only cover the period up to 1936 and are not homogeneous with those which appear in the third source, Giarda (1968), that covers the period 1937-1965. Notice that because of the presence of lagged variables among the regressors when we actually fitted the model to this latter period we could only consider the years $1940-1965$

${ }^{5}$ Data in appendix. For the rate of interest see De Mattie (1967) Table 20; for the money supply see the same source, Tables 5, 6, 7, 14, 23 (items $2 a$ and 2b) and 2 (items $2 a, 2 b$ and 7 ); the remaining series are from ISTAT (1957). For the period 1937-1946 we have been using the data that appear in Giarda (1968) except for the money supply (wide money) which is not given in this data source. Our variable (in appendix) is the sum of Biglietti E Monete Nelle Mani del Pubblico, Assegni Circolari E Vaglia, C/C Ordinari E di Corrispondenze Liberi, C/C Postali, Depositi Bancari, Libretti Postali and Buomi Postali Fruttiferi. Al1 these data from B.B.I. various issues. 
6

The rationale for this procedure is provided by Laidler and Parkin (1970) footnote 12. Șee also Jacobs (1974).

${ }^{7}$ We are referring to the U.K. and U.S.A. See Feige (1967) and Laidler and Parkin (1970).

${ }^{8}$ There is a problem here in the sense that the nominal quantity of money is usually viewed as being set exogenously by the central bank. Fortunately our results suggest that we are not dealing with an adjustment lag which of course gets rid of the problem.

9 Empirical evidence on the demand for money in the U.S.A. and in the U.K. has found that $\beta$ is significantly lower than one whereas $\alpha$ is not. Similar results have been found for Italy during the post-World War II period. There is for Instance a study by Fazio (1969) (it covers the period 1951-1968 and uses data and estimating techniques that are quite different from ours) that draws the conclusion that "The estimated parameter $\alpha$ is not significantly different from one, which suggests that the process of adjustment of actual money balances takes place, on average within the year".

${ }^{10}$ Given the importance of the result we wanted to investigate on it even further. After all there still are economists who belfeve that our naive Model 1 is appropriate and who would say that the results given in Table 2' are difficult to accept because of the presence of a non-significant interest rate variable. In order to cope with this kind of criticism the hypothesis has been tested on the basis of Mode1 1. The complete results are avallable on request; here for obvious reasons of space we will only give the estimated d-coefficients and, in brackets, the t-statistics. 1867-1936: 1.05 (17.05); 1880-1936: 1.10 (26.61); 1890-1936: $1.12(30.41) ; 1900-1935: 1.12$ (27.26); 1910-1936: 1.05 (24.04); 1940-1965: .89(23.63). 
${ }^{11}$ We note that the $z \in$ follows first order moving average process. Thus one could apply weighted non-linear least squares or maximum likelihood estimation (see Nicholls, Pagon and Terrell (1975)). Alternatively one could estimate our model using Klein's method (see Maddala (1977)) directly before using Kayck's transformation. However in this paper we have approximated it by first order autoregressive process for the simplicity of estimation as done earlier in the seminal works of Feige (1967) and Laidler and Parkin (1970).

${ }^{12}$ For this period we have homogeneous data so that the F-test is meaningful. At the same time we have enough observation and we may break the interval into two non-overlapping sub-intervals.

${ }^{13}$ This amounts to saying that if anything we are stacking the cards against the nu11 hypothesis.

${ }^{14}$ The test can be found in Chow (1960); in this case the critical F-value is equal to 237 , its actual value .03 .

${ }^{15}$ If we look at the results obtained by Friedman (1958), Laidler (1966, 1969) and Shapiro (1973) we notice that, for instance, over the last century the elasticity of the demand for money with respect to permanent income tends to fall in the interval between 1.5 and 1.8 ; for Italy we have obtained 1.54 for the period up to 1936 (see Table 5) and 1.61 for the remaining three decades (see Table 4). Again for the U.S.A. and over the period 1915-1963 $\propto$ has been found to be not significantly different from one and we too are familiar with this kind of result. Finally our adaptive expectations parameter is also close to the value that turned out in studies on the U.S.A. economy.

Following a suggestion made by David Laidler we have also been looking at the = empirical evidence on the demand for money in South American Latin countries but we discovered that there are no similarities with Italy. Both Chile and Argentina 
have fairly high coefficients on permanent income (which rise as we move from $M B$ to MI) and their money markets have also been found to adjust fairly slowly, $\alpha$ being equal to .4-.5. See Hynes (1967) and Diz (1970).

${ }^{16}$ See Vaciago (1977), p. 344 and Faz1o (1969).

${ }^{17}$ This is confirmed by the fact that even over the period 1946-1965 a short-term rate of interest performs very poorly.

${ }^{18}$ I am grateful to David Laidler for drawing my attention to this point. ${ }^{19}$ See Laidler (1977), p. 15 .

${ }^{20}$ Recently the direction of the effect has been questioned by Policiano and Chol (1978); however empirical studies by Cagan (1956), Lerner (1956) Friedman and Schwartz (1963) and Ezekiel and Adekunle (1969) all seem to lend support to the Friedmanian view that the rate of inflation affects the demand for real money balances in a negative way.

${ }^{21}$ For the period 1867-1936 because of the presence of negative rates of inflation we had to take $\log (\dot{\mathrm{p}}+17)$.

${ }^{22}$ The autocorrelation of the annual rates of price change is equal to -.045 (between $t$ and $t-1),-.349(t$ and $t-2),-.112(t$ and $t-3$ ) and -.027 $(t$ and $t-4)$.

${ }^{23}$ When, unexpectedly, the war ends wholesalers, retallers and producers start throwing their inventories on the market; at the same time, in the hope of future lower prices, consumers abstain from purchasing commodities. As a result, In spite of the sinking exchange rate and the tremendous rate of money creation prices first stop rising and then even fall in absolute values for a few months. 
${ }^{24}$ Actually it is unfortunate that periods of rapid inflation also coincide with periods of war and, as a consequence, of expectations of instability which may cause a decline in velocity as people try to accumulate real money balances. On this point see Friedman (1970) pp. 13 and 15.

${ }^{25}$ On this issue see Spinelli (1976) and Fratianni (1977). 


\section{REFERENCES}

Cagan, P., 1956, "The Monetary Dynamics of Hyperinflation," in: M. Friedman, ed., Studies in the Quantity Theory of Money, (University of Chicago Press, Chicago) 25-117.

Chow, G., 1960, "Test of Equality Between Sets of Coefficients in Two Linear Regressions," Econometrica, 28, 3, 591-605.

De Mattie, R., 1967, I Bilanci Degli Instituti Di Emissione (Banca d'Italia). D1z, A., 1970, "Money and Prices in Argentina, 1935-1962,"1n: D. Meiselman, ed., Varieties of Monetary Experiences, (University of Chicago Press, Chicago) 7-67.

Einzig, P., 1935, War Finance, 1914-1935 (Macmillan, New York.)

Ezekie1, H. and J. Adekunle, 1969, "The Secular Behaviour of Income Velocity: An International Cross Section Study," I.M.F.Staff Papers, 22, 239-278. Fazio, A., 1969,"Base Monetaria E Contro1lo Del Credito in Italia, "Moneta E Credito, June, 677-774.

Feige, E., 1967, "Expectations and Adjustments in the Monetary Sector,"American Economic Review, LVII, May, 462-673.

Fratianni, M., 1977, "Inflation and Unanticipated Changes in Output in Italy," paper presented at the Carnegle-Rochester Conference on Public Policy, Apr11.

Friedman, M., 1959, "The Demand for Money: Some Theoretical and Empirical Results," Journal of Political Economy, 67, 4, 327-351.

Friedman, M., 1970, "A Theoretical Framework for Monetary Analysis,"In: J. Gordon, ed., Milton Friedman's Monetary Framework - A Debate with his Critics, (University of Chicago Press, Chicago).

Friedman, M. and A. Schwartz, 1963, "A Monetary History of the United States, 1867-1960," (Princeton University Press, Princeton). 
Frowen, S. F. and P. Arestis, 1976, "Some Investigation of Demand and Supply Functions for Money in the Federal Republic of Germany, 1965-1974," We1twirtschaftliches Archivis, 136-163.

Giarda, P., 1968, "La Doranda Di Moneta in Italia: Un Modello Econometrico," Rivista Internazionale Di Scienze Sociali, LXXVI, 4, 601-640.

Gray, M. B. Ward and G. Zis, 1976, "The World Demand for Money Functi on: Some Preliminary Results," in: M. Parkin and G. Zis, eds., Inflation in the World Economy, (Manchester University Press, Manchester) 151-177.

Griliches, Z., 1961, "A Note on Serial Correlation Bias in Estimates of Distributed Lags, "Econometrica, 29, 65-73.

Hynes, A., 1967, "The Demand for Money and Monetary Adjustment in Chile," Review of Economic Studies, XXXIV, 2, 285-293.

ISTAT, 1957, "Indagine Statistica Sullo Sviluppo Del Reddito Nazionale De11' Italia Dal 1861 al 1956," Annali, Vol. VI.

Jacobs, R. L., 1974, "Estimating the Long-run Demand for Money from Time-Serles Data," Journal of Political Economy, 82, 1221-1237.

Klein, B., 1975, "Our New Monetary Standard: The Reassessment and Effects of Price Uncertainly, 1880-1973," Economic Inquiry, XIII, 461-484.

Klein, B., 1976, "The Social Cost of the Recent Inflation: The Mirage of Steady 'Anticipated' Inflation, Journal of Monetary Economics, L, 185-212.

Laidler, D., 1966, "The Rate of Interest and the Demand for Money...Some Empirical Evidence," Journal of Political Economy, LXXIV, 543-555. Laidler, D., 1969, "Some Evidence on the Demand for Money," Journal of Political Economy, 77, 55-68.

Laidler, D., 1977, "Demand Management in Britain from a Monetarist Viewpoint," paper presented at the Conference on Demand Management, London, December. 
Laidler, D. and M. Parkin, 1970, "The Demand for Money in the U.K.: Some Preliminary Results," Manchester Schoo1, 3, 187-208.

Lerner, E., 1956, "Inflation in the Confederacy - 1861-65," in: M. Friedman, ed., Studies in the Quantity Theory of Money, (University of Chicago Press, Chicago), 163-175.

Logue, D. and T. Willet, 1976, "A Note on the Relation Between the Rate and Variability of Inflation," Economica, 43, 151-158.

Maddala, G. S., 1977, Econometrics, (McGraw-Hill, New York).

Nicholls, D. F., A. R. Pagan and R. D. Terre11, 1975, "The Estimation and Use of Mode1s with Moving Average Disturbance Term: A Survey," International Economic Review, 16, 1, 113-134.

Pifer, H. W., 1969, "A Non-Iinear Maximum I.ikelihood Estimate of the Liquidity Trap," Econometrica, 27, 2, 324-332.

Policano, A. and E. Choi, 1978, "The Effects of Relative Price Changes on the Household's Demand for Money," Journal of Monetary Economics, forthcoming. Shapiro, A., 1973, "Inflation, Lags and the Demand for Money," International Economic Review, 14, 1, 81-96.

Spine11i, F., 1976, "The Determinants of Price and Wage Inflation: The Case of Italy," in: M. Parkin and G. Zis, ed., Inflation in Open Economies (Manchester University Press, Manchester), 201-234.

Vaclago, G., 1977, "Monetary Policy in Italy: The Limited Role of Monetarism," Banca Nazionale De1 Lavoro Quarterly Review, 123, 333-341. 